\title{
Legislative Approaches for Regulation of the Bankruptcy: State and Prospects
}

\author{
Margarita S. Bachvarova \\ Correspondence: Margarita S. Bachvarova, University of Economics, 9002 Varna, Bulgaria. \\ Received: July 22, 2016 Accepted: August 5, $2016 \quad$ Online Published: August 15, 2016 \\ doi:10.11114/bms.v2i3.1807 \\ URL: http://dx.doi.org/10.11114/bms.v2i3.1807
}

\begin{abstract}
The present article is a comprehensive research focused on the issue of legislative approaches for regulation of bankruptcy in individual countries. The occurrence of economic crises and the globalization in international relations put forward the issue of preserving viable enterprises regardless of any financial hardships arisen and any risk of initiating a court procedure of bankruptcy. The establishment of updated legislation is inextricably bound up with the building up of a theoretical concept of insolvency based on the contemporary doctrinal achievements and practice. The comparative legal analysis of regulations shows the efforts put in science for the creation of a common concept and approach to bankruptcy issues. In this relation, the subject of scientific and research interest are the characteristic features of the legal regulations for handling insolvency in individual countries, determined by their belonging to the two main legal systems: the system of common law and the continental legal system (civil law).

The scientific thesis in the present study is that regardless of the specific features of the historical and legal regulation of the bankruptcy concept, currently, a process of introducing rehabilitation procedures of the US legislation (Chapter 11 of Bankruptcy Code) into the individual legal systems of a number of countries in Europe is going on. In this sense, a trend is arising of applying a single legislative approach related to the concept of fresh start of conscientious entrepreneurs and an opportunity of sanitation of their enterprises before the initiation of formal judicial proceedings of bankruptcy on the basis of mutual concessions and compromises made by the creditors.
\end{abstract}

Keywords: law, bankruptcy, procedure, liquidation, reorganization, debtor, creditor, court

\section{Introduction}

The development of bankruptcy law is related to the following categories: venditio bonorum, distraction bonorum and cession bonorum created by the Roman civilists. They are based on the aim of proportionate satisfaction of creditors out of a debtor's property which, in most cases, used to be transferred to them voluntarily. Distractio bonorum is the closest to the bankruptcy nowadays. The similarity is based on the appointment of a guardian (curator) having functions close to the ones of administrator (receiver), related to disclosure of the debtor's property, filing resolutory claims, encashing the bankruptcy estate and its allocation among the creditors. Unlike it, the concept of cessio bohorum contains the idea of proportionate satisfaction of the creditors with the debtor's consent and preservation of the latter's minimum existence funds. In this sense, the genesis of the concept relates to the period of development of Roman law in the Middle Ages, where a debtor's insolvency would affect most of all the creditor's interests, and public interests are not infringed at that stage. Roman law perceives as a concept the presence of the debtor's fault, and the idea of insolvency existing through no one's fault arises at a later stage in result of the evolution of Roman jurisprudence.

A milestone in the historical development of the concept is marked with the international exchange in medieval Italy. The political fragmentation of the country caused a necessity for fast development of insolvency proceedings and creation of mechanisms for easy satisfaction of the creditors' interests. The stipulation of an agreement as a tool for termination of proceedings and vesting supervision functions in the court, constitutes a gain and an achievement of the Italian bankruptcy law.

The adoption of Ordonnance in France in 1673 is of fundamental significance. The Ordonnance is deemed to be the first Trade Code. Nevertheless the predominant material legal nature of the matter, it regulates both trade and non-trade bankruptcy. The following may be deemed innovations and achievements: regulation of invalidity of transactions regards the creditors, a changed principle of the creditors' voting which is not determined by their number but the total of receivables, the cases are heard at special trade courts. 
In UK the bankruptcy concept has its own evolution independent from continental Europe. The first information dates back to 1542. (McCormack, 2012) In 1543 King Henry VIII approved the first bankruptcy act but the contemporary legislation began developing in 1825 where the first bankruptcy acts were passed. The Bankruptcy Act was adopted in 1914 and it was improving constantly. As a result of some legislative reforms made, it was transformed into the Insolvency Act in 1986.

In USA the historical information of legal regulation of bankruptcy dates back from 17.09.1787, where Art. 1 of Section 8 of the Constitution provided for a uniform act to be established on the US territory. That was assigned to the exclusive competence of the Congress. The first Bankruptcy Act was adopted in 1898. The basic reform in that area was made after 1970, and a special code, the Bankruptcy Code, has been in existence since 1979. The US legislation has been differing from the English one since and it has been getting closer to the continental European regulations. It is expressly highlighted that the initiation of bankruptcy proceedings should not be necessarily related to a debtor's insolvency, and preliminary out-of-court procedures of settling the relations between a debtor and his creditors are allowed.

A process of harmonization of the European legislations, acknowledged officially in the European Commission's reports, started in 2011. For setting up a new legal frame, the Commission outlined basic guidelines for legislation reformation and their adjustment to make them comply with the economic situation for overcoming the consequences of the 2008 economic crisis. They are related to the enterprise restructuring at an early stage; retained control by the debtor over the assets, obligatory nature of the reorganization plan, adopted as per the provisions of the national legislation if approved by the court; facilitated process of restructuring by negotiations through mediators or appointment of a supervision body for monitoring.

\section{Literature Review}

Specialized literature (McCormack, 2012), (Dupoux\&Nerguarian, 2012) has been studied for the purposes of research, written by researchers of bankruptcy matter (Paulus\&Berberich, 2012) (Kilborn, 2012), legal systems and normative acts in developed economic countries with traditions and practices in that area. (Toube, Wheeler\& Roberts, 2009), Regulations of the European Commission.(Commission's recommendation, 2014).The basic conclusion to be drawn as a result of the study is that the US legislation stands out for its approach for the debtor's rehabilitation (Iancu,2012). The fresh start concept is also in this relation, and it is approved and involved in the reforms of the American law (Porter \& Thorne, 2006), followed by a number of undertaken legislative reforms in Europe. The fresh start concept is basically qualified as both legal and cultural by its nature, since it assumes the debtor's exemption from his personal responsibility for the obligations under certain conditions (Tabb, 1990).

In continental Europe, originally legal acts are focused on the liquidation of an insolvent debtor's asset. Material legislative changes have been undertaken since 1982 following Kenneth Cork's summarized report when the normative acts regards bankruptcy and the practice were studied in England. It includes the proposal for setting up mechanisms of recovering the enterprise profitability and carrying out a reform enhancing the chances of survival of enterprises suffering hardships, which is in the creditors' long-term interest. Cork's report is followed by legislation reforms and, as a result of them, the Insolvency Act of 1986 is passed.

Issues regards bankruptcy legal framework are subject of a broad discussion in Europe with the purpose of limiting any differences in the national acts at regulating the concept (Wessels, 2006). The basic finding is that regardless of the impossibility of creating a universal model, common features exist in the individual legislations. They are summarized as principles of corporate bankruptcy (Goode, 2011) and abstract formulations serving as a common base for the legislation modernization. Reforms have been gradually made (Report of the European Commission, 2012) in the European countries' national legislations focused on the regulation of procedures protecting the debtor's interests in a manner giving him a second chance to preserve his business. The legislations of Austria, Belgium (2010 and 2013), Estonia (2008), France (2006 and 2014), Germany (1999 and 2012), Greece, Latvia (2010), Malta, the Netherlands, Italy, Poland and Romania (2003 and 2006), Spain (2004 and 2013), Sweden, United Kingdom (2002) are mentioned in this relation (Wessels, 2015). The Regulation in chapter 11 of the US Bankruptcy Code turns out to be of major significance. It contains legal mechanisms of solvency recovery and debt restructure. Because of the specific features of the individual legislations though, at this stage it is impossible to create a universal model of bankruptcy proceedings applicable within Europe. Any approved principles that may become a base of future harmonization of the national legislations are also of great importance (Wood, 2007).

The researches on corporate bankruptcy maintain the proposition that investors' intentions of investing resources in insolvent companies, which are going to recover their viability successfully in the future, may also be outlined. (Adler, 1997). It is important to make an overall assessment and an assessment of the effective legal regime of bankruptcy in this relation. To maximize the value of the assets, it is necessary for the creditors to act jointly and their allocation to be 
performed as per their rights prior to the bankruptcy. Practical experience shows that the preservation of a working enterprise in its entirety while applying rehabilitation procedures holds a higher economic potential than its liquidation through the sales of its individual assets (Brower, 2006).

\section{Methodology}

The lack of unity regards the terms used in the separate legislations is typical from a methodological point of view. The countries representing the continental legal system (France, Germany) introduce the term insolvency, and in the USA and England bankruptcy is the term approved. Thus some authors define it in broad sense as "inability to pay creditors", but depending on the context, the analysis is facilitated also by the accounting, financial and legal theory (Armour, 2001). The similarity in the separate legal systems appears in the presence of explicit regulation comprising a set of rules and standards regulating any public relations arising between a debtor suffering financial difficulties and his creditors. For the purposes of the present study, based on the above, the general methodological base is in studying bankruptcy as an independent legal concept with an immanent presence in the objective law of each individual country. The basic scientific methods applied are a normative and comparative-legal method, analysis, deduction, induction, synthesis, summary aiming at establishing the legislative approach in the various legal systems.

In view of the objectives of this study, the normative theory (also called procedure theory) applies as a theoretical model for explaining bankruptcy. It is based on the general principle that bankruptcy legislation should maximize the returns and benefits of any persons with rights against the debtor (Mooney, 2004). The concept of bankruptcy regulation by law as a sub-type of a civil process lies in the basis of the procedure theory. Its basic participants are the a debtor and his creditors who exercise their rights jointly under the supervision of the court and/or a person authorized by it for the purpose of recovering their receivables from the debtor's property at most.

Two basic concepts laying the foundations of the legislative approaches in the individual countries have been studied. The idea of granting conscientious entrepreneurs with a second chance was adopted in Europe in 2012. Its key feature is the changed legislative approach that should shift its focus from the liquidation of enterprises having financial difficulties to rendering help for overcoming them, which constitutes the first step of the European Union towards the creation of culture of "rescue and recovery".(Report of the Commission, 2012). The Commission establishes in its analyses that the efficiency of bankruptcy proceedings does not depend on the legal system type: common law or civil law, but on the specific regulations providing for procedures of early warning and of healing and recovery.

The American law is based on the fresh start concept, that is particularly influential regards individuals' insolvency. It is based on the idea of exemption from debt with maximum satisfaction of the creditors' receivables in view of the debtor's property. Thus the legislative approach is focused on the consumers and the procedures develop within short terms and without any excessive formalities.

A significant methodological issue is the systematization of legal criteria allowing the application of a unified legislative technique in separate countries. For that reason, the scientific analysis is concentrated on the legal regulation of the typical representatives of the two legal systems: USA and England - of the Anglo-Saxon system, and France and Germany - of the continental legal system. A complex of features of the legal regulation is established on the basis of the comparative legal method, on one hand, and a trend of introducing separate elements from a different system, on the other hand.

In England the regulations recognize persons' qualification and for this reason they differ as follows: company insolvency - company winding up, and insolvency of individuals - bankruptcy. The basic procedures include a company voluntary arrangement (under the Insolvency Act 1986) administration, administrative receivership, winding-up and compromises and arrangements (Toube, Wheeler \& Roberts, 2009). The Insolvency Act of 1986 г. provides for a debtor's chance to propose an individual voluntary agreement with the creditors (IVA) as an alternative to proceedings. In its legal nature it is a proposal where separate debts may be paid off by transfer of shares or their payment off may be offset against the income, or just some of the debts to be paid back over a certain period of time. The proposal is subject to approval by a licensed person (receiver) who has the obligation to call a meeting of the creditors. In order to have general binding power, it is necessary the majority of creditors to give their approval.

The following procedures apply in USA depending on the request and any documents enclosed thereto, and namely: a) as stipulated by chapter 11 of the Bankruptcy Code, that assumes reorganization, where a debtor would keep control over the property and suggest a plan to be approved by the court; b) as stipulated by chapter 7, that regulates liquidation. In its essence it is sales of the debtor's assets, and then the creditors are satisfied out of the proceeds in an order that may be determined by the federal laws; c) in accordance with chapter 12 applicable to farmers. The procedure is expressed in restructuring any debts of those who have fixed annual revenue. The characteristic feature is that the debtor would keep his property and pay back the creditors out of future income; d) in accordance with chapter 13 applicable to individuals provided that they have steady income and they would like to keep some of their assets. An important 
feature is also the fact that such legal disputes are heard in special courts (bankruptcy courts). As for the persons, the normative regulation applies to individuals, companies (corporations) and partnerships. The initiative is assigned to the debtor himself and to his creditors, and criminal responsibility is stipulated in the supposition of fictitious bankruptcy adjudgment.

Following the amendments made to the Code de commerce in France in 2006, the legislative focus falls on setting up procedures aiming at overcoming financial difficulties and avoiding formal legal proceedings of bankruptcy. The main objectives of the normative regulation are related to the preservation of a working company, maintaining its work places and taking into account the creditors' rights. The area of bankruptcy law application is not limited by the type of the person, so it refers to both legal entities and individuals. Proceedings are initiated by the debtor within 15 days from suspension of payments. Creditors may use the proceedings to file a request for debt reconstruction or company winding-up. The legal regime provides a variety of procedures: a) mandate ad hoc and conciliation; and b) court controlled pre-insolvency (safeguard) and insolvency proceedings - judicial reorganization and judicial liquidation. The company workers are entitled to take part in the proceedings. The legislation maintains the position that the debtor's financial difficulties are temporary, and thus special attention is paid to any recovery procedures. In case no real chance exists for the company to continue its business or its liabilities exceed its valuation as a working company by far, liquidation proceedings are undertaken. The court plays a key role in controlling the proceedings compared to the creditors' rights.

Significant changes occurred in Germany in 1994 with the passing of the Insolvency Act. The area of insolvency proceedings application covers both individuals and legal entities. The legislative approach is related to protection of the creditors' interests by using the company assets. The main goal of the Act is to guarantee fair and proportionate satisfaction of the receivables and preservation of the debtor's business. A significant role in the proceedings is assigned to the meeting of the creditors. Any recovery of the debtor's enterprise is allowed based on a plan approved by the meeting of the creditors with a majority and confirmed by the court. Contemporary German law recognizes the concept of out-of-court agreement causing the proceedings termination, if the debtor and the creditors reach an agreement that there are not interested in its continuation. In 2012 the legislation was updated by the adoption of the Act for subsequent facilitation of company restructuring that made changes in the Insolvency Act. The main objectives of the reforms refer to expanding legal regulations for sanitation of enterprises through a change in the recovery proceedings and the proceedings of own management. A new moment in the legislation is the introduction of out-of-court protection proceedings held when a threatening insolvency exists. The term describes a condition where a reasonable conclusion may be made of the debtor's inability to pay his debts upon their maturity. The debtor is given a term of three months to propose a plan of the company sanitation.

\section{Results}

Based on the study completed, it has been established that individual countries use the following legal criteria that may become a base of unified legislative techniques at the insolvency proceedings regulation; a) the legally protected interest; b) objectives the legislation is based on; c) application scope by the type of the passive subject (respondent) who proceedings are allowed to be initiated against; d) the type of individual courts; e) the object of reorganization that may be the entrepreneur himself or his business; f) the availability of reorganizational procedures;

A legally protected interest turns out to be a criterion serving as a base for setting up legislative models which determine the ratio between the rights and obligations of the persons involved in the proceedings. According to the protection intensity, we distinguish the procreditor system, where the creditors' interests dominate. It exists in two types: a) radical (England), where the application of liquidation procedures and ultimate allocation of the debtor's assets in favor of the creditors' receivables is typical; and b) moderate (Germany), where various mechanisms of the debtor's company preservation are stipulated. Apart from the above, we also distinguish the prodebtor system, which is radically oriented to the debtor's interest protection in some countries (France). The French system is particularly indicative where the insolvency proceedings are divided into two phases: the first one is focused on the company preservation and recovery, and the second phase - on the court liquidation, revealing the features of proceedings for universal forced execution.

A differentiated legislative approach is established in view of the competence at adjudging disputes. In some countries the proceedings are heard in special courts: bankruptcy courts in USA. In most countries court procedures are under the jurisdiction of the general civil courts. The individual national legislations are reformed through the regulation of special procedures and mechanisms of the debtor's business sanitation. In some of them, such as Germany, the legal regulation is focused on the business recovery, and in the US, England and France the main objective is the enterprise reconstruction.

Out-of-court healing proceedings are set up in the modernization process of the legal regulations in Europe, which develop under the supervision of the court or an administrative body. They provide a debtor with financial difficulties 
with an opportunity to make a recovery at a stage preceding the insolvency proceedings and avoid a court procedure. Therefore, the uniting moment in the individual legislations is the orientation of the legal regulations not to the debtor's penalties, but rather to the regulation of the relations between him and his creditors through mutual compromises and debt restructuring.

The European Commission recommends the reforms in the national legislations in Europe to follow chapter 11 of the bankruptcy regime in USA. The basic guidelines are any enterprises that may recover their viability to do it as per a restructuring plan with the creditors within a year. The insolvency procedure harmonization enhances the chance of returns of the creditors' receivables. (Wilkinson, Ewer \& Stephenson, 2015). Corporate recovery is reviewed as a vital force playing a role in the economic and social development of a country. Opinions of convergence between the countries are expressed of the nature of insolvency through the introduction of compulsory procedures being an alternative to liquidation and which guarantee the fair treatment of the creditors and protection of the debtors' interests (Broc \& Barry, 2004).

\section{Conclusion}

The main conclusion of this scientific study is of the occurrence of a normative process of convergence between the separate legal systems: the common law system and the continental legal system. The basic argument is the modernization of the legislations in Europe, based on chapter 11 of the US Bankruptcy Code, on the way to signing an agreement (adoption of a reorganization plan) between the debtor and his creditors. Parallel effect of two arising trends is outlined: on one hand, harmonization of the European national legislation, and mutual penetration of independent legal concepts (convergence) between countries belonging to different legal systems, on the other hand. The main legislative approach is focused on overcoming the company financial difficulties before any payment suspension occurs through the introduction of out-of-court proceedings, which based on an agreement, within short periods, provide an opportunity of overcoming the debtor's insolvency.

\section{References}

Adler, B. E. (1997). Theory of Corporate Insolvency. New York University Law Review, $72(2), 378$-380. http://www.nyulawreview.org/sites/default/files/pdf/NYULawReview-72-2-Adler.pdf

Armour, J. (2001). The law and Economics of Corporate insolvency: A review. ESRC Centre for Business Research, University of Cambridge, Working Paper, 197, 3-15.

http://www.econ.jku.at/members/Buchegger/files/Juristen/armour_2001_corporate\%20insolvency.pdf

Broc, K., \& Barry, R. (2004). Corporate Rescue: An Overview of Recent Developments from Selected Countries in Europe. Kluwer Law International, 236-237.

Brower, M. (2006). Reorganization in US and European Bankruptcy law. European Journal of Law and Economics, 22(1), 5-20. http://dx.doi.org/10.1007/s10657-006-8978-2

Commission Recommendation of 12.3.2014 on a new approach to business failure and insolvency.7-10. Available at http://ec.europa.eu/justice/civil/files/c_2014_1500_en.pdf

Dupoux, C., \& Nerguararian, C. (2012). National Report for France. In D. Faber \& N. Vermunt \& J. Kilborn \& T. Richter (Eds) Commencement of Insolvency proceedings, (pp.284-295) Oxford University Press.

Good, R. (2011). Principles of Corporate Insolvency Law. Sweet \& Maxswell, 93-107. http://www.sweetandmaxwell.co.uk/Catalogue/ProductDetails.aspx?recordid=4535

Iancu. L. (2012). The framework of insolvency law. 221-224. Available at http://fse.tibiscus.ro/anale/Lucrari20122/AnaleFSE_2012_2_033.pdf

Kilborn, J. (2012). National Report for the United States. In D. Faber, N. Vermunt,. J. Kilborn, \& Richter, T. (Eds) Commencement of Insolvency proceedings, (pp.753-762), Oxford University Press.

McCormack, G. (2012). National Report for England. In D.Faber,, N.Vermunt, J,Kilborn, \& T. Richter (Eds) Commencement of Insolvency proceedings, (pp.234-245), Oxford University Press.

Mooney, C. W. J. (2004). A Normative Theory of Bankruptcy Law: Bankruptcy as (is) Civil Procedure, Washington and lee law Review, 61(3), 938. http://scholarlycommons.law.wlu.edu/cgi/viewcontent.cgi?article=1405\&context=wlulr

Paulus, C., \& Berberich, M. (2012). National Report for Germany. In D. Fabe, N. Vermunt, J. Kilborn., \& T. Richter (Eds) Commencement of Insolvency proceedings, 313-317, Oxford University Press.

Porter, K., \& Thorne, D. (2006). The failure of bankruptcy‘s fresh start.Cornell Law Review, 92(67), 71-74. http://www.lawschool.cornell.edu/research/cornell-law-review/upload/porterthorne_92-1.pdf 
Report of the Commission to the European Parliament, the Council and the European economic and social council. Strasburg,12.12.2012,.8-12. http://ec.europa.eu/justice/newsroom/civil/news/140312_en.htm

Tabb, C. J. (1990). The Scope of the Fresh Start in Bankruptcy: Collateral Conversions and the Dischargeability Debate. George Washington Law Review, 59(1), 56.

Toube, F., Wheeler, J., \& Roberts, K. (2009). England and Wales) In F.Toube (Ed) International Asset tracing in insolvency, 2-9, Oxford University press.

Wessels, B. (2006). The Changing Landscape of International Insolvency Law in Europe. 19-22. http://bobwessels.nl/download/changing_landscape.pdf

Wessels, B. (2015). Business Rescue in Insolvency Law-Changing the laws and challenges for the profession, 1-3. http://bobwessels.nl/wp/wp-content/uploads/2015/11/Wessels-2015-08-Business-rescue-TvOB-final.pdf

Wilkinson, A., Ewer, K., \& Stephenson, K. (2015). What's next for insolvency law reform in Europe: a pan-European insolvency law? Butterworths Journal of International Banking and Financial Law, 435-437. http://ec.europa.eu/justice/ civil/files/swd_2014_61_en.pdf

Wood, P. R. (2007). Principles of International Insolvency, 10-12. Sweet \& Maxwell. http://www.sweetandmaxwell.co.uk/Catalogue/ProductDetails.aspx?recordid=2393

This work is licensed under a Creative Commons Attribution 3.0 License. 